\title{
Investment Arbitration, Investment Treaty Interpretation, and Democracy
}

\author{
Andreas Kulick*
}

\begin{abstract}
It has become a widespread concern in recent years that there exist frictions between international investment law and arbitration and democratic governance. In particular, investor-state tribunals can issue awards that may reverse, at least de facto, decisions by democratically legitimated and democratically accountable domestic decision-makers that are deemed pivotal, by those decisionmakers, for the pursuit of the public interest of their constituency. The pressure on domestic and regional decision-makers to find responses to such frictions, through treaty-drafting or otherwise, has increased considerably in recent years and arguably has led to a shift in the official policy of traditional proponents of the established system of international investment law and arbitration. This paper explores the potential and the pitfalls of democracy as an argumentative topos informing our view on investment arbitration and the interpretation of international investment agreements, with a specific focus on the allocation of interpretative authority among the contracting parties, investor-state tribunals and state-state tribunals.
\end{abstract}

\section{Keywords}

Investment Law and Arbitration, Treaty Interpretation, Democracy, Sovereignty, Trusteeship

\section{The perceived problem of democratic legitimacy and states' reassertion of control}

Ever since the tribunal in Asian Agricultural Products Ltd $v$ Sri Lanka ${ }^{1}$ issued the first arbitral award based on an international investment agreement (IIA), there has been a constant flow of investment treaty arbitration disputes and awards, currently numbering

* Senior research fellow in public international law, and German and comparative constitutional law at the Eberhard Karls University Tübingen (Germany). I wish to thank Dr Johannes W Flume for fruitful discussions on democratic legitimacy and accountability.

1 International Centre for the Settlement of Investment Disputes Asian Agricultural Products Ltd v Republic of Sri Lanka (1990) 30 ILM 577. 
more than $500 .^{2}$ The number of awards increased and so did the amounts claimed. Further, the IIA provisions did not merely sanction expropriation without compensation, but allowed, through clauses such as fair and equitable treatment and indirect expropriation, for more subtle ways of host states depriving investors of their rights. Consequently, nationalisations or other direct expropriations became rather rare, arguably a success attributable to the increasing web of IIAs. ${ }^{3}$ Instead, governmental measures of a more general nature, including legislation or other regulatory activity, came under scrutiny in investor-state disputes. ${ }^{4}$

With the focus of these disputes changing or at least widening, it became increasingly apparent that many of them were fundamentally different from commercial disputes between private actors or classical public international law disputes between sovereign states, but rather displayed a considerable resemblance to domestic public law litigation. ${ }^{5}$ These disputes permit the control of the exercise of public authority, followed by a sanction (usually monetary damages or compensation), the enforcement of which is quite effective. Indeed, if the claims target, for example, a statute or even a far-reaching governmental response to a financial crisis, ${ }^{6}$ what makes the dispute functionally different from administrative or even constitutional judicial review?

However, while similar to domestic public law disputes in function and effect, investor-state dispute settlement differs in that the adjudication is international, ie beyond the sphere of influence of the host state, and the treaty instruments on which

2 United Nations, 'Recent Developments in Investor-State Dispute Settlement (ISDS)-Updated for the Multilateral Dialogue on Investment' (United Nations Conference on Trade and Development (UNCTAD) 28-29 May 2013, IIA Issue Notes No 1) 3, fig $2<$ http://unctad.org/en/PublicationsLibrary/ webdiaepcb2013d3_en.pdf> accessed 18 September 2015; United Nations, 'World Investment Report: Investing in the SDGs-An Action Plan' (UNCTAD, 2014) 124, fig III.13 <http://unctad.org/en/ PublicationsLibrary/wir2014_en.pdf> accessed 24 September 2015.

3 See Andreas Lowenfeld, 'Investment Agreements and International Law' (2003) 42 Columbia J Transnatl L 123, 129-30.

4 See Mara Valenti, 'The Protection of General Interests of Host States in the Application of the Fair and Equitable Treatment Standard' in Giorgio Sacerdoti and others (eds), General Interests of Host States in International Investment Law (CUP 2014) 38-54.

5 See Gus Van Harten, Investment Treaty Arbitration and Public Law (OUP 2007) 48-50; Stephan W Schill, 'International Investment Law and Comparative Public Law-An Introduction' in Stephan W Schill (ed), International Investment Law and Comparative Public Law (OUP 2010) 10-17; Andreas Kulick, Global Public Interest in International Investment Law (CUP 2012) 94-97; Andreas Kulick, 'Book Review: International Investment Law and Comparative Public Law’ (2011) 22 EJIL 917. See also generally, David Schneiderman, Constitutionalizing Economic Globalization-International Investment Law and Democracy's Promise (CUP 2008); Santiago Montt, State Liability in Investment Treaty Arbitration: Global Constitutional and Administrative Law in the BIT Generation (Hart Publishing 2009).

6 See, for instance, International Centre for the Settlement of Investment Disputes CMS Gas Transmission Company v Argentine Republic (2005) 44 ILM 1205; CMS Gas Transmission Company v Argentine Republic (Decision of the Ad Hoc Annulment Committee) ICSID Case No ARB/01/8 (25 September 2007); G\&E Energy Corp, LG\&E Capital Corp and LG\&E International Inc v Argentine Republic (Decision in Liability) ICSID Case No ARB/02/1 (3 October 2006); El Paso Energy International Company v Argentine Republic (Award) ICSID Case No ARB/03/15 (31 October 2011); Poštová banka as and ISTROKAPITAL SE $v$ Hellenic Republic (Award) ICSID Case No ARB/13/8 (9 April 2015). See also the pending case, Cyprus Popular Bank Public Co Ltd v Hellenic Republic, ICSID Case No ARB/14/16 (pending). 
the claims are based in the vast majority of cases, only deal with investor rights but do not take into account the various interests at stake if issues of public interest are brought to litigation. This is what I have called elsewhere the 'public interest challenge. ${ }^{7}$ Since the early 2000s, calls from literature and public opinion to find ways to take issues of public interest into account in investor-state dispute settlement have not-or at least not yet-found resonance in arbitral decisions. What is even more, and this leads to the topic of the present paper (and what is perceived as one of the most problematic issues), investment disputes often deal with domestic policies determined by democratically elected and accountable domestic decision-makers. Not infrequently, such policies represent the outcome of complex domestic deliberation processes that articulate the express will of the democratically legitimated majority. IIAs grant investment arbitration tribunals the power to review such policies and to sanction an encroachment on investor rights enshrined in the treaty, while at the same time they fail, at least for the most part, to recognise legitimate issues of public interest. The model of private adjudication, the ad hoc nature of the arbitral panel and the increasing but still limited level of public access to the proceedings ${ }^{8}$ are all factors that fuel what has been perceived for more than a decade now as the 'legitimacy crisis' of international investment law. ${ }^{9}$

Such a crisis of (democratic) legitimacy-whether perceived or real-has left the ivory tower of academia, and is starting to resound in public opinion and policy. After three decades of proliferation of investor-friendly IIAs enfranchising the investors to bring international claims against their host states and, accordingly, proliferation of investor-state disputes, public opinion is changing from indifference or ignorance towards international investment law and arbitration to predominantly scepticism or even fierce opposition. ${ }^{10}$

7 Kulick, Global Public Interest (n 5) 50-52.

8 However, transparency has improved significantly in investment arbitration with the amended ICSID Arbitration Rules of 2006 and the recent UNCITRAL Rules on Transparency of 2014. See ICISD Arbitration Rules (as amended and entered into force 10 April 2006) <https://icsid.worldbank.org/ICSID/StaticFiles/ basicdoc/CRR_English-final.pdf> accessed 18 September 2015; UNCITRAL Rules on Transparency in Treaty-based Investor-State Arbitration (adopted 16 December 2013, entered into force 1 April 2014) $<$ http://www.uncitral.org/pdf/english/texts/arbitration/rules-on-transparency/Rules-on-Transparency-E. pdf $>$ accessed 18 September 2015. However, it is hard to deny that the level of transparency in an investorstate dispute rarely equals the level of openness domestic public law adjudication usually displays.

9 See Susan D Franck, 'The Legitimacy Crisis in Investment Treaty Arbitration: Privatizing Public International Law Through Inconsistent Decisions' (2004-05) 73 Fordham L Rev 1521; David Schneiderman, 'Legitimacy and Reflexivity in International Investment Arbitration: A New Self-Restraint?' (2011) 2 JIDS 471. See generally Van Harten, Investment Treaty Arbitration and Public Law (n 5) 175-84.

10 Note that even The Economist has recently published a piece doubting the added value of investor-state dispute settlement and promoting an exclusively inter-state dispute settlement system modelled on the WTO Dispute Settlement Understanding. See 'A Better Way to Arbitrate' The Economist (11 October 2014) $<$ http://www.economist.com/news/leaders/21623674-protections-foreign-investors-are-not-horror-criticsclaim-they-could-be-improved> accessed 24 September 2015; 'The Arbitration Game' The Economist (11 October 2014) <http://www.economist.com/news/finance-and-economics/21623756-governments-aresouring-treaties-protect-foreign-investors-arbitration> accessed 24 September 2015. 
This is spurred by the fact that, over the course of the past ten to fifteen years, the old capital exporting countries of the West have realised that bilateral investment treaties (BITs) are not a one-way street, but indeed thus: bilateral. Originally intended to warrant investors from wealthy, predominantly Western countries a certain standard of protection, IIAs, so the old proponents of investment protection realise, can be targeted as much at their policies as they have been targeted at the policies of their treaty partners from the so-called developing world. Regulatory states with complex regimes for protection and conciliation of a myriad of different interests existing in a modern civil society, so it is submitted by many, are particularly prone to fall prey to a system of international investment law and arbitration that is not designed to make the careful balancing choices required of judicial decision-making in complex societal structures. ${ }^{11}$ To name but a few examples from recent years, Germany has been requested to pay damages for its decision to phase out nuclear energy, ${ }^{12}$ Australia faces a claim by Philip Morris for its plain packaging legislation, ${ }^{13}$ and Spain is subject to numerous claims for withdrawal of subsidies to the solar energy sector. ${ }^{14}$ The pressure on decision-makers to recalibrate treaty standards and dispute settlement is high. Democratic governments in particular find themselves in the uncomfortable position that their constituencies are calling for an overhaul or termination of their current IIA policies, while at the same time they remain locked into treaty obligations that they have advocated for themselves not such a long time ago.

Moreover, the world economy is becoming more and more complex and intertwined. Not only is the classical dichotomy between capital exporting (developed) states and capital importing (developing) states becoming blurred, but there is also a growing tendency among developing or emerging economies to conclude BITs amongst each other. ${ }^{15}$ These changes in economic realities and IIA parties bring about a veritable change of IIA contracting parties' policy with regard to international investment law and arbitration. I posit that we are currently witnessing a paradigm shift where IIA contracting parties are severely reasserting control over IIAs and the arbitration process or at least attempting to do so.

11 I only refer to the numerous submissions by non-governmental organisations to the consultations by the European Commission on investor protection in TTIP, which, in the vast majority, expressed general concerns with regard to investor-state dispute settlement and investment law in general. See, eg, Online Public Consultation on Investment Protection and Investor-to-state Dispute Settlement (ISDS) in the Transatlantic Trade and Investment Partnership Agreement (TTIP) <http://trade.ec.europa.eu/ consultations/index.cfm?consul_id=179> accessed 2 July 2015. See also generally Kulick, Global Public Interest (n 5) 77-167.

12 Vattenfall $A B$ and others $v$ Federal Republic of Germany, ICSID Case No ARB/12/12 (pending).

13 Philip Morris Asia Limited v Commonwealth of Australia, PCA Case No 2012-12 (UNCITRAL) (pending).

14 For instance, AES Solar and Others $v$ Spain (UNCITRAL) (pending); RREEF Infrastructure (GP) Limited and RREEF Pan-European Infrastructure Two Lux Sàrl v Kingdom of Spain, ICSID Case No ARB/13/30 (pending); Antin Infrastructure Services Luxembourg Sàrl and Antin Energia Termosolar BV v Kingdom of Spain, ICSID Case No ARB/13/31 (pending); NextEra Energy Global Holdings BV and NextEra Energy Spain Holdings BV $v$ Kingdom of Spain, ICSID Case No ARB/14/11 (pending).

15 See UNCTAD, World Investment Report 2014 (n 2) 114-16. 
Examples supporting the notion of a paradigm shift are myriad. Contracting parties are increasingly commencing inter-state arbitrations, such as the recent Ecuador $v$ United States arbitration; ${ }^{16}$ they make use of, or are seriously considering making use of, joint interpretations of specific treaty provisions; ${ }^{17}$ they terminate their IIAs and/or the Convention on the Settlement of Investment Disputes between States and Nationals of Other States or launch a general overhaul of their BIT regime; ${ }^{18}$ they make increasing use of frivolous claim mechanisms, such as rule 41(5) of the Arbitration Rules of the International Centre for the Settlement of Investment Disputes (ICSID), ${ }^{19}$ or consider introducing similar mechanisms into IIAs; ${ }^{20}$ they include definitions of standards such as fair and equitable treatment or indirect expropriation into their (model) IIAs; ${ }^{21}$ they consider introducing appeal mechanisms or facilitations to challenging an investment treaty arbitration award; 22 and on the European Union (EU) level, the European Commission is contemplating a regime for extra-EU BITs that foresees a number of control mechanisms for the contracting parties over investment disputes and the

16 Republic of Ecuador v United States of America (Award) PCA Case No 2012-5 (29 September 2012).

17 See on this issue generally JR Weeramantry, Treaty Interpretation in Investment Arbitration (OUP 2012) 2.39-2.51; Vienna Convention on the Law of Treaties (adopted 23 May 1969, entered into force 27 January 1980) 1155 UNTS 331 (VCLT), arts 31(3)(a)-(b): 'There shall be taken into account, together with the context: (a) Any subsequent agreement between the parties regarding the interpretation of the treaty or the application of its provisions; (b) Any subsequent practice in the application of the treaty which establishes the agreement of the parties regarding its interpretation.'

18 See Convention on the Settlement of Investment Disputes between States and Nationals of Other States (adopted 18 March 1965, entered into force 14 October 1966) 575 UNTS 159; UNCTAD, World Investment Report 2014 (n 2) 114. See also UNCTAD, 'Denunciation of the ICSID Convention and BITs: Impact on Investor-State Claims' (IIA Issues Note No 2, December 2010) <http://unctad.org/en/Docs/ webdiaeia20106_en.pdf> accessed 23 December.

19 ICSID, 'Rules of Procedure for Arbitration Proceedings (Arbitration Rules)' <https://icsid.worldbank.org/ ICSID/StaticFiles/basicdoc/partF.htm> accessed 18 September 2015.

20 ICSID Arbitration Rule 41(5) has been introduced in April 2006. See Rudolf Dolzer and Christoph Schreuer, Principles of International Investment Law (2nd ed, OUP 2012) 282-83. See also the European Commission's leaked position paper in the negotiations for the Transatlantic Trade and Investment Partnership (TTIP) of 2 July 2013, 47, No 12 <http://keionline.org/sites/default/files/eu-kommissionposition-in-den.pdf> accessed 17 September 2015: '[T]he agreement will include provisions dealing with manifestly unjustified claims.'

21 See European Commission-Directorate General for Trade, 'Investment Provisions in the EU-Canada Free Trade Agreement (CETA)’ (26 September 2014) <http://trade.ec.europa.eu/doclib/docs/2013/november/ tradoc_151918.pdf $>$ accessed 2 July 2015.

22 See European Commission-Directorate General for Trade, 'Factsheet on Investor-State Dispute Settlement' (3 October 2013) 4-5 <http://trade.ec.europa.eu/doclib/docs/2013/october/tradoc_151791. pdf> accessed 2 July 2015: '[T]he EU believes that on the basis of the agreements we have signed with our trading partners there should be a debate setting up an appeals mechanism for ISDS disputes. This would also lead to greater consistency in how the provisions of investment agreements are interpreted.' See the discussion within ICSID dating back until 2004: ICSID Secretariat, 'Possible Improvements of the Framework for ICSID Arbitration' (Discussion Paper, 22 October 2004) <https://icsid.worldbank.org/apps/ ICSIDWEB/resources/Documents/Possible\%20Improvements\%20of\%20the\%20Framework\%20of\%20 ICSID\%20Arbitration.pdf $>$ accessed 24 September 2015. On possible appeals mechanisms in international investment arbitration, see the various contributions in Karl P Sauvant (ed), Appeals Mechanism in International Investment Disputes (OUP 2008). 
interpretation of the agreement-and has pushed for the termination of all intra-EU BITs altogether. ${ }^{23}$

State practice exhibits a number of examples. Germany, for instance, the world's BIT champion, with over 130 such treaties concluded, ${ }^{24}$ now calls for the re-introduction of the local remedies rule in new IIAs to which it or the EU may become a party. ${ }^{25}$ Its government hesitates to agree to include a chapter providing for investment protection and investor-state dispute settlement mechanisms in EU free trade agreements under negotiation, such as the Comprehensive Economic and Trade Agreement and the Transatlantic Trade and Investment Partnership. ${ }^{26}$ If enacted, Germany would abandon a decades-old tradition of investment-friendly foreign economic policy. Similarly, there is an ongoing discussion within the government of the Netherlands calling into question the established investment policy which led to a recent general impact study of investor-state dispute settlement. ${ }^{27}$ Further, I have already mentioned some initiatives and considerations with regard to the EU investment policy.

Public opinion is also a factor in why all contracting parties, including the traditional capital exporters, will be more and more prone to push for a restrictive interpretation of their old, liberal IIAs. Adding to this, of course, is the aforementioned increased likelihood that both contracting parties may find themselves in the respondent seat in an investor-state arbitration. The quasi-precedential effect of investment arbitration awards and decisions plays a significant role here. As is established practice in investorstate arbitration, tribunals frequently refer to prior decisions on other IIAs and the argumentation employed therein as persuasive authority. ${ }^{28}$ Hence, only a change in case

23 See European Commission-Directorate General for Trade, 'Factsheet' (n 21); European Commission, 'Towards a comprehensive European international investment policy' COM (2010) 343 final.

24 According to UNCTAD, as of December 2014, Germany has concluded 134 BITs that are still in force: see UNCTAD -Division on Investment and Enterprise, 'Investment Policy: International Investment Agreements Navigator' (2013) <http://investmentpolicyhub.unctad.org/IIA/CountryBits/78\#iiaInnerMenu> accessed 2 July 2015.

25 See the official position of the German government: Federal Ministry for Economic Affairs and Energy, 'Frequently Asked Questions about the Transatlantic Trade and Investment Partnership (TTIP)' (2015) <http://www.bmwi.de/EN/Topics/Foreign-trade/TTIP/faq.html> accessed 2 July 2015: 'When is investorto-state dispute settlement needed? (...) It should only be possible to initiate investor-to-state dispute settlement as a last resort after exhausting the legal process before the national courts.'

26 ibid: 'The German government takes the view that special investment protection provisions are not required in an agreement between the EU and the US as both parties provide sufficient legal protection through their national courts.'

27 See Christian Tietje and Freya Baetens, 'The Impact of Investor-State-Dispute Settlement (ISDS) in the Transatlantic Trade and Investment Partnership' (Study prepared for the Minister for Foreign Trade and Development Cooperation, Ministry of Foreign Affairs, The Netherlands, 24 June 2014).

28 See Christoph Schreuer and Matthew Weiniger, 'Conversations Across Cases-Is There a Doctrine of Precedent in Investment Arbitration?’ (5 January 2007) <http://www.univie.ac.at/intlaw/conv_across_90. pdf> accessed 2 July 2015; Irene M Ten Cate, 'The Costs of Consistency: Precedent in Investment Treaty Arbitration' (2012-13) 51 Columbia J Transnatl L 418, 436-47. For an example from the case law, see Impregilo SpA v Argentine Republic (Award) ICSID Case No ARB/07/ 17, para 108:

It is true that (...) the jurisprudence regarding the application of MFN clauses to dispute settlement provisions is not fully consistent. Nevertheless, in cases where the MFN clause has referred to 'all 
law will reduce the risk for the contracting parties to find themselves subject to awards that clash with fundamental domestic policies, including important public interest issues, often enacted after careful deliberation of democratically elected and legitimated domestic institutions. Therefore, in a nutshell, reassertion of control as described here serves as the contracting parties' vehicle to link their international investment law policies to their (domestic) democratic accountability.

For the purpose of this paper, 'democracy' shall denote, in Abraham Lincoln's famous words, 'government of the people, by the people, for the people ${ }^{29}$ - that is, majority rule, usually through elected bodies, qualified by a concern to protect the rights of minorities and the opposition. One important aspect of this basic understanding of democracy is accountability. Democratic governments have to answer for their decisions to their people, the demos, and are elected (or not) because their decisions reflect the will of the demos (or not). ${ }^{30}$ Such accountability entails 'the great privilege', as Alexis de Tocqueville noted, of 'being able to repair the faults [one] may commit ${ }^{31}$ - that is, of changing policy and adapting it to what is in the best interest of the demos and/or what accords to its will. Hence, 'democratic government requires that the citizens can give their input to decisions of law and policy, and that political processes produce outputs in the interest of the citizens. ${ }^{32}$

\section{Democracy and IIA interpretation}

This contribution focuses on the potential of democracy to serve as a theoretical foundation for IIA interpretation, in particular the allocation of interpretative authority among the stakeholders of investment dispute settlement and treaty interpretation. Hence, it does not discuss the potential impact of considerations of democracy and democratic accountability on other aspects of international investment law and arbitration including,

matters' or 'any matter' regulated in the BIT, there has been near-unanimity in finding that the clause covered the dispute settlement rules. On this basis, the majority of the Tribunal reaches the conclusion that Impregilo is entitled to rely, in this respect, on the dispute settlement rules of the Argentina[-United States] BIT and that the case cannot be dismissed for non-observance of the requirements in Article $8(2)$ and (3) of the Argentina-Italy BIT.

This reliance on decisions of other investment tribunals considering different IIAs is fuelled by what Stephan Schill termed the 'multilateralization' of international investment law-that is, the fact that many IIAs contain very similar language, which invites tribunals to cite decisions on similar clauses in other IIAs indiscriminately. See generally Stephan W Schill, The Multilateralization of International Investment Law (CUP 2009). However, as noted by many, such indiscriminate reference often brushes over subtle or not so subtle differences in treaty language and thus is prone to draw conclusions that cannot be drawn. See, for instance, Cate (n 28) 447ff.

29 Abraham Lincoln, 'Gettysburg Address' (Infomotions Inc 2001) 1.

30 See Anne Peters, 'Dual Democracy' in Jan Klabbers, Anne Peters and Geir Ulfstein (eds), The Constitutionalization of International Law (OUP 2009) 265-66.

31 Alexis de Tocqueville, Democracy in America (Bantham 2000) vol 1, 268.

32 Peters, 'Dual Democracy' (n 30) 265. 
inter alia, procedural aspects, such as transparency, arbitrator selection, public access and publication of decisions, or the profile and selection of arbitrators. ${ }^{33}$ Those are pivotal aspects of the relationship between international investment law and democracy and, in particular, the perceived deficit of democratic legitimacy of investor-state arbitration. However, I focus here on IIA interpretation and how and to what extent democracy can be employed as an argumentative topos.

The relationship of democracy and IIA interpretation features two main aspects. First, what is the (potential) impact of democracy as an argumentative topos on the interpretation of specific treaty clauses, such as 'fair and equitable treatment', 'discriminatory and arbitrary measures', 'full protection and security' and the like? Secondly, what can democracy as an argumentative topos tell us about the allocation of interpretative authority among the relevant stakeholders? As foreshadowed above, in this contribution I choose to concentrate mainly on the second question. This is not only for lack of space, but also because this issue is the more general and theoretically more interesting one that may, in turn, also influence our understanding of the first question. For this reason, I will be very brief with regard to the first aspect.

Investment arbitration awards have been severely criticised for not taking into account the host state's democratic accountability and the mechanics of democratic deliberation processes. ${ }^{34}$ For example, Gus Van Harten claims that some arbitrators appeared to view electorally and politically-accountable processes with suspicion as opposed to the respect that courts often show. ${ }^{35}$ He uses Tecmed $v$ Mexico in particular as a showcase, where the tribunal refuted 'political circumstances' induced by responses of the Mexican authorities to 'community pressure' as a legitimate ground for the decision not to renew the operating permit. ${ }^{36}$ Indeed, such portrayal of democratic processes would be problematic both under the Tocquevillian account of democracy as the ability to make 'repairable mistakes, ${ }^{37}$ as well as under the Habermasian account of democracy

33 For an account of these matters, see Barnali Choudhury, 'Democratic Implications Arising from the Intersection of Investment Arbitration and Human Rights' (2008-09) 46 Alberta L Rev 983, 1005-07; Steffen Hindelang, 'Part II: Study on Investor-State Dispute Settlement ("ISDS") and Alternatives of Dispute Resolution in International Investment Law' in Directorate-General for External Policies Policy Department, Investor-State Dispute Settlement (ISDS) Provisions in the EU'S International Investment Agreements (European Parliament 2014) vol 2, 98-104 <http://www.europarl.europa.eu/RegData/etudes/ STUD/2014/534979/EXPO_STU(2014)534979_EN.pdf> accessed 23 December 2015; Eric de Brabandere, Investment Treaty Arbitration as Public International Law (CUP 2014) 148-74. With regard to international courts and tribunals generally, see Armin von Bogdandy and Ingo Venzke, In Wessen Namen?Internationale Gerichte in Zeiten Globalen Regierens (Suhrkamp 2014) 218-54.

34 See, for instance, Schneiderman (n 5) 3, 16 and 206; Gus Van Harten, Sovereign Choices and Sovereign Constraints (OUP 2013) 68-76.

35 Van Harten, Sovereign Choices and Sovereign Constraints (n 34) 72.

36 ibid 73-74, citing Técnicas Medioambientales Tecmed SA v United Mexican States (Award) ICSID Case No ARB (AF)/00/2 (29 May 2003) paras 128, 132, 151.

37 Schneiderman (n 5) 13 (paraphrasing Alexis de Tocqueville (n 31)). 
as deliberative process. ${ }^{38}$ However, looking at more recent case law, the picture does not look as dreadful. For instance, the tribunal in Paushok $v$ Mongolia recognised precisely de Tocqueville's yardstick of the ability to repair mistakes as the defining characteristic of democratic process and rejected the claimant's attempt to portray such process alone as evidence of frustration of its legitimate expectations that leads to a breach of the 'fair and equitable treatment' standard:

[T] he fact that a democratically elected legislature has passed legislation that may be considered as ill-conceived, counter-productive and excessively burdensome does not automatically allow to [sic] conclude that a breach of an investment treaty has occurred. (...) Legislative assemblies around the world spend a good part of their time amending substantive portions of existing laws in order to adjust them to changing times or to correct serious mistakes that were made at the time of their adoption. ${ }^{39}$

Equally, the Electrabel decision took account of the deliberative element of democracy by stressing that political considerations are 'necessarily' at the heart of decision-making by democratically accountable governments. Consequently, the tribunal refused to see such political deliberation process as evidence for arbitrariness and a frustration of legitimate expectations, stating that 'politics is what democratic governments necessarily address. ${ }^{40}$

In a similar fashion, Continental Casualty $v$ Argentina acknowledged the specific accountability of the democratically elected Argentine government to its people with regard to 'restor[ing] civil peace and the normal life of society' for purposes of interpreting the emergency clause of article XI of the US-Argentina BIT. ${ }^{41}$

Finally, democratic accountability may serve a role with regard to compensation. I recall Ian Brownlie's separate opinion in CME $v$ Czech Republic. ${ }^{42}$ When determining the amount of compensation to be awarded, according to Brownlie, a tribunal must be attentive to 'the significance of the fact that the Respondent is a sovereign State, which is responsible for the well-being of its people. ${ }^{43}$ Brownlie illustrated that there is a considerable difference between a corporation and a state with regard to allocation of assets for paying damages:

38 See Jürgen Habermas, Between Facts and Norms: Contributions to a Discourse Theory of Law and Democracy (W Rehg tr, MIT 1996) in particular 104-10. See also Steven Wheatley, The Democratic Legitimacy of International Law (Hart Publishing 2009) 102-06.

39 Sergei Paushok, CJSC Golden East Company and CJSC Vostokneftegaz Company v Government of Mongolia (Award on Jurisdiction and Liability) UNCITRAL (28 April 2011) para 299.

40 Electrabel SA $v$ Republic of Hungary (Decision on Jurisdiction, Applicable Law and Liability) ICSID Case No ARB/07/19 (30 November 2012) para 8.23. See also AES Summit Generation Limited and AES-Tisza Erömü Kft v Republic of Hungary (Award) ICSID Case No ARB/07/22 (23 September 2010) paras 10.3.2310.3.24, which also Van Harten mentions: Van Harten, Sovereign Choices and Sovereign Constraints (n 34) 74.

41 Continental Casualty Company v Argentine Republic (Award) ICSID Case No ARB/03/9 (5 September 2008) para 174.

42 CME Czech Republic BV (The Netherlands) v Czech Republic (Final Award) UNCITRAL (14 March 2003) (Separate Opinion of Sir Ian Brownlie).

43 ibid para 74. 
The resources of a corporation entail considerable flexibility in changing the location of assets and in changing the organisation of assets. The resources of a country, its human and natural resources, are a given: they are necessarily fixed. ${ }^{44}$

Such difference, says Brownlie, must be taken into account when calculating the damages due by a respondent state in an investment arbitration. ${ }^{45}$

\section{Allocation of interpretative authority among investor-state tribunal, state-state tribunal and the contracting parties with regard to democratic accountability}

\subsection{Reassertion of control, agency, trusteeship and investment arbitration}

The reassertion of control as described above means an attempt to shift power, back from the investor and the investor-state tribunal to the contracting parties. One of the motives for the intended power shift is the perception, among the contracting parties themselves and among their civil societies, that a system that at least may adjudicate issues of public interest must take such public interest into account. ${ }^{46}$ If the contracting parties to IIAs take control over the agreements and/or the arbitration, the question arises as to whether contracting parties have the right and should be the only trustees of the public interest. The answer to this question, in turn, depends on how much control the contracting parties are legitimately able to assert.

International relations theory offers models of agency and trusteeship to explain why states delegate authority to international courts and tribunals. ${ }^{47}$ Under a principalagent model, states (principals) delegate authority to international courts and tribunals (agents) to resolve international disputes for reasons of efficiency-that is, because a tribunal is better placed to resolve a dispute than the parties to the dispute themselves. ${ }^{48}$ The trusteeship model, by contrast, follows a different rationale, focusing on credibility and independence rather than efficiency. According to this model, states delegate

44 ibid para 76.

45 See also case law of the European Court of Human Rights, where the Court held that 'exceptional circumstances' might justify expropriation without any compensation: Case of the Holy Monasteries $v$ Greece App nos 13092/87, 13984/88 (ECtHR, 9 December 1994) para 71; Case of Jahn and Others $v$ Germany ECHR 2005-V 630, paras 116-17. See on this also Andreas Kulick, 'Sneaking Through the Backdoor-Reflections on Public Interest in International Investment Arbitration' (2013) 29 Arbitration Intl 435.

46 See Kulick, Global Public Interest (n 5) 151.

47 See Andrew T Guzman, 'Why LDCs Sign Treaties that Hurt them' (1998) 38 VJIL 639; Anthea Roberts, 'Power and Persuasion in Investment Treaty Interpretation: The Dual Role of States' (2010) 104 AJIL 179, 186.

48 See, for instance, Eric Posner and John Yoo, 'Judicial Independence in International Tribunals' (2005) 92 California L Rev 1, 6-7, 14; Tom Ginsburg, 'Bounded Discretion in International Judicial Lawmaking' (2005) 45 VJIL 631, 641-44. 
authority to international judicial bodies because the decision of a neutral third party increases the confidence in, and credibility of, their commitments and other obligations under public international law. ${ }^{49}$ This entails an aspect of legitimacy because of the international control of national decision-making by ideally independent international judicial bodies. ${ }^{50}$ The reach of agents' and trustees' authority is defined and thereby limited by their respective underlying rationales of efficiency (agency) and credibility (trusteeship). Under a trusteeship model the permissible level of control to be exerted by the contracting parties to a treaty providing for international judicial dispute resolution is hence lower than under an agency model. ${ }^{51}$

Following Anthea Roberts' classification, I agree with her overall assessment that the present system of investment arbitration is a hybrid of agency and trusteeship models. ${ }^{52}$ Investor-state tribunals are trustees of dispute resolution. One of the main purposes of the current system of investment law and arbitration is investment promotion through international legal standards and international adjudication beyond the full control of the host state. ${ }^{53}$ Such a legitimising function may only be achieved by a relatively independent judicial body that is entrusted with settling the dispute between the investor and the host state. Moreover, notably, with regard to investor-state dispute resolution as such, the principals are here the contracting parties (or, to be more precise, one of them-that is, the host state), on the one hand, and the investor, on the other hand. The IIA makes investor-state arbitration possible and usually provides for the contracting parties' general consent to this form of dispute resolution. However, a specific dispute to be resolved can only be introduced by the investor. ${ }^{54}$ Hence, an agency model based exclusively on the contracting parties' consent to dispute resolution would be inaccurate to capture the specific features of investment arbitration.

Nonetheless, some features of investment law and arbitration may not be fully explained by a trusteeship model either. ${ }^{55}$ Dispute resolution proper is not the only task bestowed upon investment law and arbitration. Rather, the interpretation of IIAs-in

49 See, for instance, Karen J Alter, 'Agents or Trustees? International Courts in their Political Context' (2008) 14 EJIR 33, 38; Laurence Helfer and Anne-Marie Slaughter, 'Why States Create International Tribunals: A Response to Professors Posner and Yoo' (2005) 93 California L Rev 899, 917.

50 See Armin von Bogdandy and Ingo Venzke (n 33) 26-27. See also, in more general terms and with regard to state-state judicial dispute settlement, Yuval Shany, 'Assessing the Effectiveness of International Courts: A Goal-Based Approach' (2012) 106 AJIL 225, 259-60.

51 See Roberts, 'Power and Persuasion' (n 47) 186-87.

52 ibid 188. See also Alec S Sweet and Florian Grisel, 'Transnational Investment Arbitration: From Delegation to Constitutionalization' in Pierre-Marie Dupuy, Francesco Francioni and Ernst-Ulrich Petersmann (eds), Human Rights in International Investment Law and Arbitration (OUP 2009) 124-26, who regard investorstate tribunals furthermore as agents of 'the greater community'.

53 See Wolfgang Alschner and Elisabeth Tuerk, 'The Role of International Investment Agreements in Fostering Sustainable Development' in Freya Baetens (ed), Investment Law within International Law: Integrationist Perspectives (CUP 2013) 217.

54 This second hybrid aspect of investor-state arbitration does not find mention in Anthea Roberts' analysis: see Roberts, 'Power and Persuasion' (n 47) 188.

55 See also the notion of constrained independence advanced in Helfer and Slaughter (n 49) 929-30. 
other words, defining the scope of investors' rights and the limits of contracting parties' lawful exercise of governmental authority-is a crucial feature that is usually intertwined with dispute resolution. That is, when resolving a dispute, an investor-state tribunal must interpret the IIA in order to determine whether the investor's claims are wellfounded or not. The investor-state tribunal shares the authority to interpret the terms of the IIA with the contracting parties-who can amend, terminate and interpret the treaty-and usually a state-state tribunal for which the IIA often specifically reserves the role to resolve disputes of interpretation between the contracting parties. Consequently, here the limits for contracting parties' reassertion of control are wider. As a preliminary conclusion, these considerations suggest that contracting parties may enjoy more leeway reasserting their control when matters of treaty interpretation are at stake compared to issues where the dispute resolution function is in the foreground.

This may translate into responses to specific doctrinal questions. These considerations may provide guidelines as to, for example, until what point in time in an investor-state dispute an instrument of reassertion of control (such as joint interpretation), may still be legitimately employed by one contracting party and when a tribunal may legitimately disregard it. Taking the example of joint interpretation, the guidelines developed here would suggest that such an interpretation would infringe upon the trusteeship bestowed upon an investor-state tribunal with regard to dispute resolution if undertaken after the request for arbitration. In that case, the purpose of the specific joint interpretation is not so much to retain general control over how the terms of the respective IIA are to be interpreted, but rather to influence the outcome of the particular dispute. That is, there is dispute resolution in favor of one contracting party rather than a genuine interest in preserving the true intention of both contracting parties with regard to the meaning of the treaty.

\subsection{Democracy and sovereignty}

At first glance, in the context of investment arbitration, sovereignty and democracy seem unlikely bedfellows. First, are international investment law and arbitration not precisely about limiting sovereignty? Secondly, is sovereignty not about, inter alia, states' free choice over their internal political system - that is, about international law's neutrality in that regard? However, this and the following subsection will explore the reach of the relationship of these two concepts-sovereignty and democracy-for the purposes of international investment arbitration and demonstrate their potential impact on IIA interpretation, while the next section will address the limits of democracy as an argumentative topos in this regard.

As already mentioned, international investment law and arbitration limit sovereignty. By concluding an IIA, the contracting parties consent to observing the rules enshrined in that treaty and thus consent to limit their freedom of action, as they do with the conclusion of any treaty. Furthermore, they usually consent to the idea that any dispute arising over the interpretation of that treaty is to be settled by an arbitral tribunal. 
Hence, the contracting parties confer-to some extent-the authority to determine the contents of the obligations the treaty imposes upon them on a third party, ${ }^{56}$ namely, the arbitral tribunal. What is even more, they consent, generally and without qualification that any investor-that is, not a contracting party, but rather a national of the other contracting party - can bring a claim before an arbitral tribunal that has the authority to determine the contents of the obligations that the treaty imposes upon the contracting parties. Consequently, sovereignty plays a pivotal role in investment arbitration. That is, investment arbitration involves the conferral of authority by the contracting authorities to the arbitral tribunal in order that it might determine the reach and limits of IIA obligations and sanction a contracting party for exercising its sovereign authority in a manner that contravenes its IIA obligations. This ceding of sovereign authority is significant, as the arbitral tribunal becomes the agent and/or trustee of the contracting parties with regard to the IIA. ${ }^{57}$

However, what is the content of the contracting parties' sovereignty that they partly cede to their agent/trustee, the arbitral tribunal? This is where democracy enters the stage. Many authors suggest that nowadays the concept of sovereignty has ventured far beyond the old Lotus paradigm. ${ }^{58}$ Sovereignty, so they argue, cannot be understood any longer as merely the freedom to do as one pleases unless one has consented to limiting that freedom. In a recent groundbreaking piece, Eyal Benvenisti reconceptualises sovereignty as trusteeship. ${ }^{59}$ The legitimacy of a state, so he argues, hinges on its role of serving as 'an important democratic venue for exercising personal and communal selfdetermination. ${ }^{60}$ In other words, the existence of states is justified by their task to pursue the public interest of their people, both internally and externally. ${ }^{61}$ Thus, sovereignty can only be understood as a vehicle to further such pursuit of the public interest on behalf of the constituency. Similarly, Christian Tomuschat writes, 'States are no more than instruments whose inherent function is to serve interests of their citizens, ${ }^{\prime 62}$ and Jeremy

56 See, for instance, Karen J Alter, The New Terrain of International Law: Courts, Politics, Rights (Princeton UP 2014) 9.

57 See ibid (with regard to international courts and tribunals in general).

58 See Case of the SS 'Lotus' (France v Turkey) (Merits) PCIJ Rep Series A No 10, 3, 18-19.

59 Eyal Benvenisti, 'Sovereigns as Trustees of Humanity: On the Accountability of States to Foreign Stakeholders' (2013) 107 AJIL 295.

60 ibid 300 .

61 See also James Crawford, 'Democracy and the Body of International Law' in Gregory H Fox and Brad R Roth (eds), Democratic Governance and International Law (CUP 2000) 92-93. In fact, one can trace back this idea at least as far as Aristotle: see Nick W Barber, The Constitutional State (OUP 2010) 38. See also Martti Koskenniemi, 'What Use for Sovereignty Today?' (2011) 1 Asian J Intl L 61, 65, who refers to Pufendorf.

62 Christian Tomuschat, 'International Law: Ensuring the Survival of Mankind on the Eve of a New Century' (1999) 281 RCADI 1, 70; Christian Tomuschat, 'Möglichkeiten und Grenzen der Globalisierung' in Jürgen Schwarze (ed), Globalisierung und Entstaatlichung des Rechts-Ergebnisse der 31. Tagung der Gesellschaft für Rechtsvergleichung vom 20. bis 22. September 2007 in Halle: Beiträge zum Öffentlichen Recht, Europarecht, Arbeits und Sozialrecht und Strafrecht (Mohr Siebeck 2008) 31ff (where Tomuschat makes some disclaimers with regard to the current state of the law); Armin von Bogdandy, 'The Telos of International Law-Christian Tomuschat's General Course and the Evolution of the Universalist Tradition' 
Waldron emphasises that 'a government is a trustee for its people's interests. ${ }^{63}$ They refer to the Universal Declaration of Human Rights ('the will of the people shall be the basis of the authority of government') ${ }^{64}$ or more recent efforts such as the 'Responsibility to Protect $^{65}$ for evidence in multilateral instruments that such understanding of sovereignty as trusteeship also finds acceptance in state practice. ${ }^{66}$ However, note that this model of sovereignty as trusteeship does not at all posit the demise of sovereignty, but instead promotes sovereignty as a vehicle for self-authorship. Martti Koskenniemi's writes of 'the hope of experiencing the thrill of having one's life in one's own hands. ${ }^{67}$ Sovereignty as trusteeship hence means that such thrill is experienced by and on behalf of the sovereign's democratic constituency. ${ }^{68}$

Of note, Benvenisti's concept of sovereignty as trusteeship makes a bolder statement than endorsed here. He posits that sovereigns are in fact trustees of humanity at large. ${ }^{69}$ However, as Joseph Weiler argued so poignantly: 'there is no convincing account of democracy without demos. (...) There is no demos underlying international governance. ${ }^{70}$ Indeed, ' $[\mathrm{w}]$ hat is required is (...) a rethinking of the very building blocks of democracy to see how these may or may not be employed in an international system which is neither State or Nation'-rethinking which is yet to occur. ${ }^{71}$ Therefore, all convincing accounts of 'dual legitimacy' that draw on both domestic and cosmopolitan democratic models eventually hinge on the link to domestic democratic legitimacy. ${ }^{72}$ I will thus limit my considerations to conclusions drawn from domestic democratic models. ${ }^{73}$

Finally, connecting the model of sovereignty as trusteeship with the model of investment arbitration as agency/trusteeship, if adjudication of investment disputes by an international arbitral tribunal means that the contracting parties to IIAs cede part

in Pierre-Marie Dupuy and others (eds), Völkerrecht als Wertordnung-Common Values in International Law: Festschrift für Christian Tomuschat (KP Engel 2006) 703, 707.

63 Jeremy Waldron, 'Are Sovereigns Entitled to the Benefit of the International Rule of Law?' (2011) 22 EJIL $315,326$.

64 Universal Declaration of Human Rights, UNGA Res 217A (III) (10 December 1948) art 21(3).

65 See International Commission on Intervention and State Sovereignty, 'The Responsibility to Protect' (2001) available at <http://responsibilitytoprotect.org/ICISS\%20Report.pdf> accessed 2 July 2015.

66 See Benvenisti (n 59) 296.

67 Koskenniemi (n 61) 70.

68 Consequently, sovereignty as trusteeship does not view sovereignty in the Schmittian sense, ie as an extralegal concept (cf Carl Schmitt, Politische Theologie (1st edn, Duncker \& Humblot 1922)), but rather as 'sovereignty within public international law': see Anne Peters, 'Membership in the Global Constitutional Community' in Jan Klabbers, Anne Peters and Geir Ulfstein (eds), The Constitutionalization of International Law (OUP 2009) 184 (emphasis in original).

69 Benvenisti (n 59) 300ff.

70 Joseph Weiler, 'The Geology of International Law-Governance, Democracy and Legitimacy' (2004) 64 Zeitschrift für ausländisches öffentliches Recht und Völkerrecht 547, 560.

71 ibid 561.

72 See, for instance, von Bogdandy and Venzke (n 33) 200, who see a 'supplementary' role of international democratic legitimacy that builds on domestic democratic legitimacy.

73 For a model of a 'non-state democratization of global governance', see Peters, 'Dual Democracy' (n 30) $296-341$. 
of their sovereign authority to the tribunal, the agency/trusteeship by the international tribunal that results from such cession can only be exercised within the confines of the sovereignty entrusted to the contracting parties. In other words, the sovereignty (partially) ceded to the arbitral tribunal necessarily implies the concept of sovereignty as trusteeship on behalf of the domestic democratic constituency. However, if, in turn, the contracting parties' sovereignty is to be understood as trusteeship on behalf of the demos of each contracting party, the investment tribunal can and may exercise its adjudicatory role granted by the contracting parties only within the confines so defined. It follows from this that public interest and domestic democratic accountability must play a considerable role in the investment tribunal's exercise of its judicial function. ${ }^{74}$ Moreover, under this view, contracting parties' reassertion of control may be employed or even in itself regarded as a means to recalibrate the investment regime towards taking due account of democratic accountability and the public interest.

\subsection{Consequences for treaty interpretation}

This brings me back to treaty interpretation, as the central function of an investment arbitration tribunal under an IIA. From the above considerations, we can draw some conclusions vis-à-vis the allocation of interpretative authority among the stakeholders involved - that is, the investor-state and state-state tribunals and the contracting parties.

Let me start again with a general account of contracting parties' reassertion of control as described above. Such reassertion of control over the IIA emanates from the relationship between an investor-state and a state-state tribunal with regard to matters of treaty interpretation: whose, if any, interpretation enjoys priority if both interpret the same clause in the same IIA differently? Anthea Roberts, when discussing the relationship of investor-state and state-state tribunal decisions with joint interpretations by the contracting parties, argues for a three-level hierarchy. ${ }^{75}$ She places joint interpretations at the top, declaring them binding on any tribunal. Second in rank comes the state-state tribunal's interpretation. To Roberts, such interpretation award is 'highly persuasive' to investor-state tribunals - that is, it creates a 'rebuttable presumption' that the state-state tribunal's interpretation is correct and is thus to be adopted. ${ }^{76}$ Investor-state awards interpreting the same treaty are at the bottom of the hierarchy and are 'just persuasive. ${ }^{77}$

I agree with Roberts that joint interpretations by the contracting parties are binding on any tribunal, be it in a state-state or an investor-state dispute. The contracting parties are the creators of the IIA and they could make way with it in an afternoon if they

74 See also Kulick, Global Public Interest (n 5) 85-94, 149-50.

75 Anthea Roberts, 'State-to-State Investment Arbitration: A Hybrid Theory of Interdependent Rights and Shared Interpretative Authority’ (2014) 55 Harvard Intl L J 1, 62-63.

76 ibid.

77 ibid. 
decided to do so. ${ }^{78}$ Further, even if articles $31(3)(a)-(b)$ of the Vienna Convention on the Law of Treaties (VCLT) merely provide that subsequent practice and agreements between the contracting parties 'shall be taken into account, together with the context' of the respective treaty, the tribunals' interpretative authority-granted by the contracting parties' agreement-can only go as far as allowed by the contracting parties' agreement. ${ }^{79}$ Further, at this point, the above argumentation with regard to sovereignty and democracy would provide support for this position. If the IIA expresses the joint will of the contracting parties, who thereby have ceded some part of their sovereignty (as trusteeship), their accountability to their domestic constituencies may speak for a prevalence of their will that an investment arbitration tribunal cannot disregard or by which it is arguably even bound. I refer here also to the Methanex case with regard to the Free Trade Commission's interpretation of article 1105(1) of the North American Free Trade Agreement, where the tribunal endorsed similar reasoning when it held that clarifying rules if courts misconstrue them is 'obligatory in a democratic and representative system in which legislation expresses the will of the people. ${ }^{80}$

With regard to the next issue, I also think that investor-state tribunals' interpretation should be at the bottom of the hierarchy. ${ }^{81}$ Provided that the respective IIA grants jurisdiction for a state-state tribunal to decide general disputes as to the interpretation of the treaty, the state-state tribunal's interpretation of treaty clauses enjoys primacy over the investor-state tribunal's interpretations. While in an investor-state dispute, the tribunal is called upon to resolve a specific matter where the interpretation of the IIA is an albeit possibly decisive corollary in a state-state dispute, the interpretation of the IIA is the very purpose why the contracting parties have created this dispute settlement mechanism.

I disagree, however, with Roberts' classification of state-state interpretative awards as a category of lower authoritative value than joint interpretations. To her, 'a stateto-state award is less persuasive than an interpretative agreement because it involves a disagreement, rather than an agreement, between the masters of the treaty. ${ }^{82}$ To

78 See Martins Paparinskis, 'International Investment Law: Analogy and Cohesiveness of International Law' (CJICL Conference, Cambridge, 11 May 2014).

79 I recognise that such understanding may be viewed as deviating from International Status of South West Africa (Advisory Opinion) (11 July 1950) [1950] ICJ Rep 128, 135-36 (where the Court stated that joint interpretations are 'not conclusive as to their meaning' but rather enjoy merely 'considerable probative value'). Indeed, it may create frictions with treaty amendments, since joint interpretations consequently have the same effect as treaty amendments. However, in this latter regard, I accept that the contracting parties do not enjoy unlimited discretion as to how the terms of the treaty can be interpreted. A tribunal must reject a joint 'interpretation' that is logically impossible and de facto amends the treaty, ie that is impossible to reconcile with the wording. Only with respect to such off-limits control may a tribunal review and reconsider the contracting parties' joint interpretation. This is what, to my mind, still preserves a difference between joint interpretation and amendment.

80 Methanex Corporation v United States of America (Final Award on Jurisdiction and Merits) (2005) 44 ILM 1345, part IV.C, para 22; North American Free Trade Agreement (adopted 17 December 1992, entered into force 1 January 1994) 32 ILM 289.

81 See Roberts, 'State-to-State Investment Arbitration' (n 75) 63.

82 ibid. 
my mind, the contracting parties, by consent to state-state arbitration, have delegated authority to the state-state tribunal to resolve their dispute over the interpretation of the IIA. Therefore, the tribunal's interpretation is the functional equivalent to a joint interpretation by the contracting parties. The contracting parties agreed that in case they cannot come to an agreement about what they intended with the treaty provision, the tribunal as an independent third party should decide. In both cases, the decision about what the treaty provision should mean has its roots in the contracting parties' agreement, not in their disagreement. The disagreement in that case is no more than the switch point that opens the path to state-state arbitration, and hence to the subsequent authoritative decision about what the treaty provision should mean, which is anchored in the consensus of the contracting parties. Here again, the democracy argument supports this position: the state-state tribunal is called upon to decide authoritatively what the contracting parties intended with a specific treaty provision if they cannot agree on a joint interpretation themselves. The authority conferred upon the tribunal stems from both contracting parties' sovereignty as trusteeship on behalf of their respective demoi, not only by the IIA itself but by their party status to the specific dispute. Such statestate tribunals' determination of the meaning of a treaty clause therefore must enjoy prevalence over the interpretation by an investor-state tribunal. The latter only contains one of the contracting parties as party to the dispute and an individual or corporation as the other party, thereby lacking that aspect of democratic accountability that the contracting parties possess.

\section{$4 \quad$ A 'gentle civilizer' ${ }^{\prime 3}$ ?}

All the above makes good material for the enthusiast of democratic liberalism. However, let us take a step back and reflect on where such reasoning, if untamed, leaves us. Inherent in our contemporary understanding of sovereignty is the idea of equality. If states are sovereign, an international order that ascribes itself to the maintenance of international peace and security ${ }^{84}$ must be founded on state equality. Hence, article 2(1) UN Charter posits the sovereign equality of states as the first principle of the UN, regardless of their internal political order. Furthermore, consider the general principle of international law, which finds expression, inter alia, in article 27 VCLT or the customary rule enshrined in article 3 of the International Law Commission Articles on the Responsibility of States for Internationally Wrongful Acts, that reference to domestic law is no justification of a breach of international law. ${ }^{85}$ Why would or could, then, the organisation of a state's

83 Martti Koskenniemi, The Gentle Civilizer of Nations (CUP 2001).

84 Charter of the United Nations (adopted 26 June 1945, entered into force 24 October 1945) 1 UNTS 16, art $1(1)$.

85 ILC, 'Draft Articles on Responsibility of States for Internationally Wrongful Acts of its 53rd Session' (2001) UN Doc A/56/10, chp.IV.E.1; see also James Crawford, State Responsibility: The General Part (CUP 2013) $100-03$. 
internal order influence the range of its rights as a sovereign on the international plane, specifically in an investment dispute before an investment arbitration tribunal? Let me explain my concerns.

The above reasoning on the role of democracy as an argumentative topos for IIA interpretation begs the question: what if a contracting party is not a democracy? In other words, what does the absence of a democratic internal system of governance mean for the range of rights of such a sovereign, particularly if the government disregards the people's (majority's) will? In that case, should an investment tribunal be less deferential towards public interest arguments brought forward by such state? Pursuant to the above reasoning, the answer would have to be yes: a state that does not pursue the public interest on behalf of its people as determined through democratic process falls short of its trusteeship role which entitles it to exercise its sovereignty. Mind-boggling questions ensue. Would a joint interpretation of two non-democratically governed contracting parties have less value with regard to interpretative authority than the joint interpretation of two democratically governed ones? What if, of the two contracting parties issuing the joint interpretation, one is democratically governed and the other one is not? As different states exhibit different levels of democratic accountability, by law and in practice, should we differentiate according to how 'good' a democracy is or how well it works? In any event, who would determine all this? If it were for the tribunal to determine, this would defeat the very purpose of granting more interpretative authority and/or deference to the contracting parties. Eventually, it would still be the tribunal who has the last word-not about the contents of the treaty obligation, but about whether a/the contracting party/ies is/are entitled to determine the contents of such obligations; and thereby ranking its/their level of democratic governance!

In any event, whether or not assessing the value or level of democratic governance and accountability were within the competence of an investment tribunal, the relevance of such assessment for the outcome of the dispute would provide tremendous opportunity for abuse among the contracting parties and might result in a considerable re-politicisation of the investment dispute. Portraying the host state as undemocratic, either by the investor or jointly with its home state, would constitute a return to gunboat diplomacy in modern cloth-only that the fusillade would take the form of an image campaign instead of gunfire.

Anne Peters has argued that differentiated treatment among states, based on their respect for democracy or human rights, may conform to the principle of sovereign equality if it takes the shape of what she calls 'proportionate equality. ${ }^{86}$ Hence, in whatever way we frame the argument, we would have to translate democratic accountability and legitimacy into legal categories that require evaluating the level of 'democracy' that an IIA contracting party exhibits. ${ }^{87}$ While there is the obvious challenge of categorisation, let us assume we were able to create such categories and make evaluation based on such categories. Under

86 Peters, 'Global Constitutional Community' (n 68) 192-93.

87 ibid 193. 
any possible scenario, we would arrive at more or less sophisticated variations of these three categories: democratic states, semi-democratic states and non-democratic states. Does this sound familiar? It should. It reminds us of late 19th century categorisations of nations-and, in consequence, political organisation-as 'civilised', 'half-civilised' and 'savage. ${ }^{88}$ The similarity is not mere folklore but demonstrates the danger that a thorough application of the democracy argument entails. It recalls Carl Schmitt's famous assessment that ' $\mathrm{t}$ ] he concept of humanity is an especially useful ideological instrument of imperialist expansion. ${ }^{89}$ Replace 'humanity' with 'democracy' and you get the idea. ${ }^{90}$ Anne Orford has unmasked similar trends with regard to exceptions of the prohibition of the use of force by way of a 'responsibility to protect' as neo-colonial tendencies ${ }^{91}$ that international investment law is well-advised not to emulate.

Anne Peters contends with regard to human rights that, according to her concept of proportionate equality, differentiation would be reversible and limited to specific instances that shift once the problematic policy is abandoned and thus would not lead to 'the creation of fixed categories of states, as in the 19th century international legal doctrine..$^{2}$ However, I am concerned that a more permanent labelling of states would be the consequence if that concept was applied based on democracy as the differentiating factor. This is particularly so because a state's political system and culture are far more static and domestically engrained than most policies with regard to specific human rights issues-not to mention that leaving such labelling to an investment tribunal appears as undesirable as leaving it to the investor or its home state.

\section{Conclusion}

In this contribution, I have fleshed out both the potentials and the pitfalls of a reasoning pondering on democracy as an argumentative topos for treaty interpretation. Hence, a tribunal that endorses such reasoning must tread very carefully in order not to fall back into argumentative patterns we hoped to have left long behind us. Democracy should not become a disguise for a neo-colonial attitude in fancy cloth. For those who are tempted

88 See, for instance, James Lorimer, Institutes of the Law of Nations: A Treatise of the Jural Relations of Separate Political Communities (Blackwood \& Sons 1883) vol 1, 101 ('civilized', 'barbarian' and 'savage'); Lassa Oppenheim, International Law: A Treatise (1st edn, Longmans, Green \& Co 1905) vol 1, 154-57. See also Koskenniemi (n 83) 70-71, 127-32; Benedict Kingsbury, 'Sovereignty and Inequality' (1998) 9 EJIL 599, 605-06, 622.

89 Carl Schmitt, The Concept of the Political (George Schwab tr, Chicago UP 2007) 54. It goes without saying that this statement should be read cum grano salis, considering Schmitt's opus and biography.

90 Benvenisti (n 59) 328 acknowledges this problematique. See also Anthea Roberts, 'The Next Battleground: Standards of Review in Investor-State Arbitration' in Albert J Van Den Berg (ed), Arbitration: The Next Fifty Years (Kluwer 2012) 178; Caroline Henckels, 'Balancing Investment Protection and the Public Interest: The Role of the Standard of Review and the Importance of Deference in Investor-State Arbitration' (2013) 4 JIDS 197, 205.

91 See, in particular, Anne Orford, International Authority and the Responsibility to Protect (CUP 2011).

92 Peters, ‘Global Constitutional Community’ (n 68) 195. 
to promote democracy as a central argumentative topos in investment arbitration, this consequence may be unintended. However, this makes it no less problematic. In fact, too much of this argumentation may lead international investment law back to an age it has gladly escaped.

So, what remains? I think that we can-and must-distinguish the concept of sovereignty as trusteeship from democracy per se. One of the pivotal issues that this contribution has fleshed out is accountability as inherent in the trusteeship model. However, while we usually associate accountability with democracy, there exist elements of accountability to their people in government forms that are not role model democracies. If we hence start with the rationale of sovereignty as trusteeship, I contend that, with regard to public interest policies on matters of high importance for the domestic society as a whole, IIA contracting parties must be granted some leeway in the choice and adoption of such policies that must find its way into investment tribunals' reasoning when assessing breaches of IIA provisions. As the Lemire tribunal acknowledged, a state enjoys an 'inherent right to regulate (...) in order to protect the common good of its people. ${ }^{93}$ Even if it might hurt the democratic heart, such an 'inherent right' should be granted any sovereign, regardless of how its internal political system is organised.

Naturally, this is not a carte blanche for disrespecting the rule of law vis-à-vis foreign investors, or international law in general, and arguably more questions arise from this conclusion than it answers or that can be addressed here. But regarding IIA interpretation, there should be some consequences to the understanding of sovereignty as trusteeship. One consequence concerns matters of deference that have been suggested and discussed brilliantly elsewhere, so that I can content myself with just mentioning the adoption of different levels of scrutiny, in particular with regard to domestic public interest legislation, and the introduction of a margin of appreciation of some sort. ${ }^{94}$ The second consequence is what I fleshed out above with regard to the allocation of IIA interpretative authority - that is, the prevalence of joint interpretations of the contracting parties and of decisions of the state-state tribunal.

93 Joseph Charles Lemire v Ukraine (Decision on Jurisdiction and Liability) ICSID Case No ARB/06/18 (14 January 2010) para 505.

94 See, for instance, Andreas von Staden, 'The Democratic Legitimacy of Judicial Review Beyond the State: Normative Subsidiarity and Judicial Standards of Review' (2012) 10 J Intl Constl L 1023 (promoting and developing the concept 'normative subsidiarity'); William Burke-White and Andreas von Staden, 'The Need for Public Law Standards of Review in Investor-State Arbitrations' in Stephan W Schill (ed), International Investment Law and Comparative Public Law (OUP 2010) 689; Henckels (n 90) 197; Stephan W Schill, 'Deference in Investment Treaty Arbitration: Re-conceptualizing the Standard of Review' (2012) 3 JIDS 577; Roberts, 'The Next Battleground' (n 90) 170. 